\title{
AN EXPLORATION OF DRIVERS AND STRATEGIES FOR ENCOURAGING THE DELIVERY OF GREEN BUILDING PROJECTS IN HOUSING DEVELOPMENT
}

\author{
Nor Kalsum Mohd Isa ${ }^{1 *}$, Mohd Yazid Mohd Yunos ${ }^{2}$, Mohd Hairy Ibrahim ${ }^{1}$, Kamarul Ismail ${ }^{1}$, \\ Mazdi Marzuki ${ }^{1}$ \\ ${ }^{1}$ Department of Geography and Environment, Faculty of Human Sciences, Sultan Idris Education \\ University, Tanjong Malim, 35900 Perak, Malaysia \\ ${ }^{2}$ Faculty of Design and Architecture, University of Putra Malaysia, 43400, Serdang, Selangor, \\ Malaysia
}

(Received: July 2018 / Revised: September 2018 / Accepted: December 2018)

\begin{abstract}
Green building has attracted increasing attention in recent years and the concept has a positive impact on the environment when adopted in the field of housing development. This study aims to explore the drivers and strategies that should be developed in order to encourage green building project delivery in housing development. This study uses an empirical approach that combines case study, quantitative, and qualitative methods. First, a questionnaire survey was distributed to housing developers in the Klang Valley (KV). A total of 234 developers returned completed questionnaires. The results of the quantitative analysis, based on descriptive statistics, Cronbach's alpha, correlation, and multiple regression analysis showed that social and cultural drivers have the greatest effect on green building project delivery by housing developers. Next, the quantitative findings were applied to a qualitative case study and two companies in KV were investigated. Finally, the results were validated by interviewing five experts in the industry. The results of the experts' interviews not only validated the findings obtained from the quantitative and qualitative analysis, but also provided in-depth explanations for the identified drivers and strategies.
\end{abstract}

Keywords: Green building; Green development; Housing development; Pro-environmental behavior; Project delivery

\section{INTRODUCTION}

\subsection{Green Building in Malaysian Housing Development}

Residential buildings account for approximately $15 \%$ of primary energy use (Kruger \& Seville, 2013). Thus, not surprisingly, the housing industry is a major cause of the increase in carbon dioxide emissions $\left(\mathrm{CO}_{2}\right)$. Carbon dioxide emissions in Malaysia increased from 14.6 million tons in 1970 to 328 million tons in 2020, placing great pressure on the environment (Tan, 2011). Meanwhile, the demand for housing has steadily increased, primarily as a result of demographic trends and rising incomes. This, in turn, has increased resource consumption and waste generation, having a negative impact on the environment.

Malaysia has shown its commitment to sustainable development by energy diversification and efficient energy utilization, starting with the formulation of the National Energy Policy 1979(NEP79), National Depletion Policy 1980 (NDP80), Four Fuel Diversification Policy 1981

\footnotetext{
"Corresponding author's email: norkalsum@fsk.upsi.edu.my, Tel. +06-05-4505134, Fax. +06-05-4598606 Permalink/DOI: https://doi.org/10.14716/ijtech.v9i8.2756
} 
(4FDP81), and Fifth Fuel Policy 2000 (5FP2000) (Chua \& Oh, 2011). The development of green technology and Malaysia's achievement in green building are demonstrated by several iconic green buildings including the Energy Commission's headquarters or Diamond Building, the Green Energy Office (GEO) building, and the Low Energy Office (LEO) building. Malaysia has been a party to international agreements such as Rio, Kyoto, and the recent United Nation's Conference of Parties (COPs). Since 2008, green development has encouraged the formulation of several transformative green policies. For example, the Government has introduced major incentives to foster green building investment and the adoption of green building in the public and private sectors in Malaysia, including the introduction of a series of green tax exemptions and reductions and investment incentives. In addition, the Malaysian Energy Centre evolved into the Malaysian Green Technology Corporation to support green technology promotion, development, and implementation (APEC, 2014). Furthermore, the government provided incentives such as stamp duty and feed-in tariffs for Malaysia's green practitioners (Isa et al., 2015; Isa et al., 2017; Isa et al., 2018). The Malaysian Prime Minister gave a remarkable speech at the Copenhagen COP15 Conference in 2009 in which he announced Malaysia's commitment to reducing carbon emissions by $40 \%$ by the year 2020. Following this, the Malaysian Government's commitment to environmental protection was explicitly stated in the Tenth Malaysia Plan which included the use of sustainable energy management systems in order to reduce the emission of GHGs and conserve existing resources. Likewise, the environmental effort continued with the Eleventh Malaysia Plan in line with Malaysia's aspirations to become a developed nation by the year 2020 through low-carbon development and the sustainable, inclusive, and efficient use of resources (The Government of Malaysia, 2015).

Extensive agreement on the principle of green development does not necessarily lead to extensive implementation. It has been argued that, although many construction practitioners agree with the green concept, many have still not grasped its meaning and even fewer have translated the concept into "green" action (Albahori \& Isa, 2017; Albahori et al., 2017). In 2016, only 28 housing projects were fully certified by the Green Building Index (GBI Malaysia) out of 818 registered housing projects delivered in the Klang Valley (KV) (GBI, 2017; MHLG, 2017). Thus, to improve the momentum of green practices in the industry, action should be directed at implementing strategies that facilitate green building project delivery. Green building is a sustainable means for investors to maintain environmental integrity and human wellbeing in the long term (Isa et al., 2015). Unfortunately, this study found that many housing developers are still hesitant to pursue the green concept in their projects. Thus, this study attempts to discover what factors stall green building project delivery by housing developers, specifically in $\mathrm{KV}$, and subsequently proposes strategies to facilitate green building project delivery in housing development.

\subsection{Encouraging Green Housing Project Delivery by Developers}

In order to have a clear understanding of the drivers and strategies that encourage green building project delivery in housing development, pro-environmental behavior (PEB) theory was used to investigate the interaction between human behavior and the environment. PEB is defined as the effort to minimize the negative impact of one's action on the natural environment (Kollmuss \& Agyeman, 2002). The significant antecedents of PEB theory were defined by two main factors: internal and external. The variables of PEB's internal factor are knowledge, emotions, values, and attitudes. Environmental knowledge is able to change a person's environmental attitude and behavior. Knowledge about the benefits to be gained from green building development is crucial as a starting point for changing developers' attitudes, values, and behavior regarding the execution of green projects (Albahori \& Isa, 2017). Emotion is the second internal factor that needs to be addressed in relation to green building implementation by developers and it is very important in shaping human beliefs, values, and attitudes towards 
the environment (Kollmuss \& Agyeman, 2002). Ekman's Atlas of Emotions (1992) was used in this study to measure basic emotions such as anger, disgust, fear, happiness, sadness, and surprise. Values are also responsible for shaping intrinsic human motivation (Ekman, 1992). Values have a positive influence on environmental behavior regarding openness to change and universalism. Attitude is a general or enduring positive or negative feeling about some person, object or issue. Attitude can directly influence developers' behavior together with their beliefs and values concerning the benefits of the green building practices. Attitude is predictive of behavior and behavioral intentions (Albahori \& Isa, 2017). In this study attitude was measured according to the willingness of developers to deliver green building development (the PEB items) in their future housing projects.

Meanwhile, the external drivers of PEB consist of institutional or political, economic, social, and cultural factors (Kollmuss \& Agyeman, 2002). The political drivers include government support in terms of various incentives, policies, regulations, technical support, and financial support (Samari et al., 2015). Social and cultural factors refer to strategies such as proper education and training; the use of recommended appliances; willingness to commit to sustainable development; promotion of a green organizational culture, belief, and reputation; and the provision of programs to increase awareness and knowledge ( $\mathrm{Li}$ et al., 2014). A successful green building project also depends on communication and coordination skills when managing people with different responsibilities and types of expertise within the construction process and throughout the building lifespan ( $\mathrm{Li}$ et al., 2014). In addition, economic factors have a strong influence on people's decisions and behavior (Kollmuss \& Agyeman, 2002).

Albahori and Isa (2017) found that in KV, the internal drivers of green building project delivery by housing developers consist of values and attitudes. This finding indicates that the positive values and attitudes of a developer regarding green building development will influence their decision to deliver such a project and vice versa. Even though knowledge and emotions were also listed as PEB items, they were not directly correlated with the delivery of green building projects in KV. Meanwhile, according to Albahori et al. (2017) only two external drivers were associated with green building delivery by housing developers; that is, social and cultural, and economic drivers. Political drivers had no evident influence on green project delivery (Albahori et al., 2017). These results showed that four drivers influenced green building project delivery in KV's housing development: values, attitudes, social and cultural, and economic factors. This study has taken the results of Albahori \& Isa (2017) and Albahori et al. (2017) as a basis for exploring the drivers that affect green building project delivery by housing developers and identifying strategies for encouraging delivery of these projects by integrating the relevant drivers. Based on the above review, a total of two internal and two external drivers of green building delivery by housing developers were finally identified. The internal drivers consisted of values and attitudes and the external drivers consisted of social and cultural and economic aspects. Strategies to encourage project delivery were then formulated based on the dimensions of these four drivers.

\section{METHODOLOGY}

This research uses an empirical approach that combines case study, qualitative, and quantitative methods. In the first step, a questionnaire survey was used to collect a large amount of empirical data, which then provided the basis for a quantitative study that explored the drivers of green building project delivery in housing development and the most significant strategies for encouraging it. In the second step, case studies of a qualitative nature were used to carry out an in-depth analysis followed by interviews with experts to ensure the validity of the quantitative findings. 


\subsection{The Klang Valley (KV) Study Area}

$\mathrm{KV}$ was the most appropriate region to be selected as the case study for this research. KV is Malaysia's main conurbation and its industrial and commercial hub. The majority of housing developers with projects throughout Malaysia have their main offices located here. 110 out of 144 green residential GBI certified buildings are located in KV. Selangor and Kuala Lumpur have the highest number of registered green projects (GBI, 2017). Thus, the housing developers in $\mathrm{KV}$ are considered to be more amenable to green development.

\subsubsection{Questionnaire survey}

A questionnaire survey was the first level of primary data collection for this research and was used to explore the drivers of green building projects and the strategies for encouraging such project delivery by housing developers in KV. The sample decisions were based on Krejcie and Morgan's Table (Krejcie \& Morgan, 1970) and the minimum sample required for this study was 234 respondents. The total population of 591 developers was divided into 11 zones based on the list of companies and the zones provided by MHLG. Four hundred printed questionnaires were distributed to the housing developers. In total, 234 completed questionnaires were received, resulting in an overall effective response rate of $59 \%$. The majority (177 out of 234) of the responses were from developers undertaking green building projects, reflecting the fact that $\mathrm{KV}$ developers are more aware and willing to deliver green building projects.

\subsubsection{Case study interviews}

Interviews were used as the second level of primary data collection in this research. The case study interviews took place after the completion of quantitative survey analysis because the design of the interview questions was based on the quantitative results. Interviews were conducted with two housing developers located in $\mathrm{KV}$, one of which delivers green projects and the other does not. The developers were interviewed regarding the drivers affecting their decision as to whether or not to deliver a green building project as part of their organization's operations. To avoid bias, the developers were selected based on their similar operations, capital, achievement, and success, but they used different approaches within the building industry. There were three criteria for choosing the developers, as follows: they should be top developer companies listed in "The Edge Malaysia Property Excellence Award" listings, should have received the "The Edge Top Property Developers Award" for their housing projects in the KV area, should be well known, and should have over ten years' experience of operating in the housing development industry. Results from the questionnaires were compared to confirm their usefulness and validity, particularly with regard to the drivers and the strategies of green building project delivery.

\subsubsection{Interviews with experts}

Interviews with experts were conducted after completion of the quantitative survey analysis and case study interviews because the design of the expert interview protocol was based on those results. The expert interviews were conducted particularly to validate the proposed strategies that were formulated from the previous stages of research. The experts were chosen based on their expertise, knowledge, and experience of developing green buildings. Five experts were interviewed: one was from GreenTech Malaysia, one was from Malaysia Green Building Confederation (MGBC), one was from Ministry of Energy, Green Technology and Water (MEGTW), one was from a developer that actively delivers green projects (company A) and one was from a developer that actively delivers conventional projects (company B) located within the KV area. The developers were identified using the criteria of top housing developers in KV as listed in "The Edge Malaysia Property Excellence Award" listings, had received "The Edge Top Property Developers Award" for their development projects in KV, and had more than ten years' experience in the building development industry. Furthermore, all five experts were chosen based on criteria that included the fact that they were well known among industry 
players; were experts in green building project delivery, or involved in the formulation of GBI Malaysia, green building policies, guidelines, or other relevant government initiatives; and belonged to a relevant industry association.

\section{RESULTS AND DISCUSSION}

\subsection{Quantitative Analysis}

\subsubsection{Profiles of respondents}

Table 1 summarizes the professional designations of the survey respondents. It indicates that $60 \%$ of respondents were male and $75 \%$ held professional positions in built environment and construction companies; that is, architect, engineer, planner, quantity surveyor, or building surveyor. Other positions comprised $2 \%$ chairman, $1 \%$ CEO, $2 \%$ director, $5 \%$ deputy director, and $17 \%$ other personnel. Clearly, the distribution of positions shows that most of them (83\%) are at the professional and managerial levels and therefore have a strong influence on decisionmaking in their respective companies. They are practicing professionals in their fields and those in executive positions have the power to determine the administration of their housing projects.

Table 1 Respondents' designations and professional fields

\begin{tabular}{lrrrrrrrr}
\hline \multirow{2}{*}{ Designation } & \multicolumn{10}{c}{ Professional Fields } \\
\cline { 2 - 9 } & Architecture & $\begin{array}{c}\text { Building } \\
\text { surveying }\end{array}$ & Engineering & $\begin{array}{c}\text { Quantity } \\
\text { surveying }\end{array}$ & $\begin{array}{c}\text { Town } \\
\text { planning }\end{array}$ & Others & Total & $\begin{array}{c}\text { Percent } \\
(\%)\end{array}$ \\
\hline Chairman & 1 & 0 & 3 & 1 & 0 & 0 & 5 & 2 \\
CEO & 1 & 0 & 0 & 1 & 0 & 0 & 2 & 1 \\
Director & 1 & 0 & 2 & 0 & 1 & 0 & 4 & 2 \\
Deputy Director & 3 & 1 & 4 & 0 & 0 & 0 & 8 & 3 \\
Professional & 32 & 23 & 48 & 27 & 44 & 2 & 176 & 75 \\
Others & 3 & 5 & 16 & 0 & 7 & 8 & 39 & 17 \\
\hline \multicolumn{1}{c}{ Total } & 41 & 29 & 73 & 29 & 52 & 10 & 234 & 100 \\
\hline
\end{tabular}

Out of the total of 234 respondents, $142(61 \%)$ had been involved in the building sector for six to ten years. $11 \%$ had 11 to 15 years' work experience. 52 respondents $(22 \%)$ had been involved in the conventional building sector for less than five years. The remainder of the respondents had been involved in this conventional sector for more than 16 years. Strikingly, $66 \%$ of the respondents had less than five years' experience of green building projects, $28 \%$ had six to ten years' experience, and $6 \%$ had between 11 and 20 years' experience. They disclosed that they gained that experience from working in other countries. Since green building is relatively new in Malaysia, it is not surprising that more than $50 \%$ of respondents $(65.8 \%)$ had less than five years work experience on green housing projects.

\subsubsection{Correlation and multiple regression analysis}

Spearman's rank correlation coefficient was used to identify the relationship between the driver variables (values, attitudes, social and cultural, and economic) and the variable of green building project delivery. There was a significant, positive correlation between the variable of green building project delivery and developer's values, between green building project delivery and developer's attitudes, between green building project delivery and social drivers, and between green building project delivery and economic drivers with a value of $p>.05$ smaller than $\alpha=.05$ (Table 2).

Multiple linear regression analysis was used to identify the actual drivers of green building project delivery. Although the data was not normally distributed, according to the central limit theorem, when the sample size is sufficiently large $(>200)$, the normality assumption is unnecessary because the central limit theorem ensures that the distribution of disturbance term will approximate normality (Statistics Solutions, 2013; Mordkoff, 2016). 
Table 2 The partial correlation results

\begin{tabular}{lccc}
\hline \multicolumn{1}{c}{ Variables } & $\begin{array}{c}\text { Spearman's } \\
\text { rho (r) }\end{array}$ & $\begin{array}{c}\text { Significance } \\
(\mathrm{p})\end{array}$ & Correlation \\
\hline Green building project delivery - values & $.167^{*}$ & .011 & Significant \\
Green building project delivery - attitudes & $.166^{*}$ & .011 & Significant \\
Green building project delivery - social and cultural & $.138^{*}$ & .035 & Significant \\
Green building project delivery - economic & $.224^{* *}$ & .001 & Significant \\
\hline$* *$ Correlation is significant at the 0.01 level (2-tailed) & & & \\
$*$ Correlation is significant at the 0.05 level (2-tailed) & & &
\end{tabular}

Therefore, the use of multiple regressions was valid because the total of respondents was greater than 200. In order to obtain the significance value, two tests of significance were used. The first test analyzed the variance (ANOVA) for the regression. The significance of this analysis depended on the value of $\mathrm{F}$ for the ratio between explained and unexplained variability of the dependent variables and all the independent variables. The second significance test involved determining whether the parameter estimates for each explanatory variable derived from the regression could be statistically significant. For this purpose, the regression analysis used the t-test as a measure of significance in which the higher values of $t$, regardless of whether they show negative or positive correlations, indicate significant results. The partial correlation shows a weak relationship between the independent and dependent variables which is lower than 0.7 and a collinearity tolerance value greater than 0.1 , indicating that the data has no multicollinearity (Table 3).

Table 3 The partial correlation and collinearity statistics

\begin{tabular}{lccccc}
\hline \multicolumn{7}{c}{ Excluded Variables $^{\mathrm{a}}$} \\
\hline Model & Beta In & $\mathrm{t}$ & Sig. & Partial Correlation & $\begin{array}{c}\text { Collinearity Statistics } \\
\text { Tolerance }\end{array}$ \\
\hline MEAN_VALUES & $.042^{\mathrm{b}}$ & .568 & .570 & .037 & .747 \\
MEAN_ATTITUDES & $.063^{\mathrm{b}}$ & .904 & .367 & .059 & .812 \\
MEAN_ECONOMIC & $.150^{\mathrm{b}}$ & 1.958 & .051 & .128 & .669 \\
\hline
\end{tabular}

a'Dependent Variable: MEAN_Green building project delivery

${ }^{\mathrm{b}}$ Predictors in the Model: (Constant), MEAN_SOCIAL

The study found that the social and cultural driver variable $(p=.000)$ had the greatest effect on green building project delivery compared to other variables, with a significance value smaller than $\alpha=0.05$. Significantly, social and cultural drivers $[F(1,232)=19.212, p<.05]$ had the strongest influence, contributing by $7.6 \%(\mathrm{R} 2=.076)$ to green building project delivery (Table 4). If the respondents' perceptions of the social and cultural drivers increases by about 1 unit, then green building project delivery will increase by approximately a 0.147 unit score. The significant variables are presented in the multiple regression models below:

$$
\begin{gathered}
\text { Green building project delivery }=0.131 \text { (constant) }+(0.165) \mathrm{X} 6 \\
\mathrm{Y}=\beta 0+\beta 6(\mathrm{X} 6)
\end{gathered}
$$

The point of intersection of $\mathrm{Y}$, when $\mathrm{X}=0, \mathrm{Y}$ is the green building project delivery (dependent variable), $\mathrm{X} 6$ is the social and cultural driver (independent variable), and $\beta 6$ indicates the coefficients for the independent variables related to the constant 0.131 .

The multiple regression result indicated that KV housing developers were primarily affected by social and cultural drivers when making decisions on green building project delivery. The result 
shows that that social and cultural drivers significantly affected $7.6 \%$ of green building project deliveries.

Table 4 The drivers affecting green building project delivery

\begin{tabular}{llllll}
\hline \multicolumn{1}{c}{ Variable } & \multicolumn{2}{c}{ Implementation } & \multirow{2}{*}{$\mathrm{t}$} & & \multirow{2}{*}{ Contribution (\%) } \\
\cline { 2 - 5 } Constant & $\mathrm{B}$ & $\beta$ & & & \\
\hline Social and cultural drivers & .131 & & & & \\
$\mathrm{~F}=19.212 \mathrm{R}=0.277$ & .165 & .277 & 4.383 & .000 & \\
Sig. $\mathrm{F}=\mathrm{p}<0.05 \mathrm{R}^{2}=0.076$ & & & & & \\
Percentage contribution $=7.6 \%$ & & & & & \\
\hline
\end{tabular}

Social and cultural drivers such as the government, stakeholders, environmental organizations, and public support are the main factors affecting green building development. Although there are relationships between the attitudes, values, and economic drivers in green building project delivery, the most important driver is the social and cultural driver. This is the area on which strategies to encourage green building project delivery in housing development should concentrate. This finding was then applied to the case study and the interviews with experts for in-depth understanding and validation purposes.

\subsection{Qualitative analysis}

\subsubsection{Case studies}

In order to obtain a more in-depth understanding of the drivers and strategies for encouraging green building project delivery, two established KV developers were studied. One company had several high profile green housing projects and the other had no practical experience of green projects. The first company was given the code D1 and the second company was given the code D2 (Table 5).

Table 5 The companies' backgrounds

\begin{tabular}{lll}
\hline \multicolumn{1}{c}{ Company name } & \multicolumn{1}{c}{ Developer 1 } & \multicolumn{1}{c}{ Developer 2 } \\
\hline Code & D1 & D2 \\
Type of practice & Green development & Conventional development \\
Company employees & $900++$ & $500++$ \\
Housing projects underway in the year 2017 & 7 projects & 9 projects \\
Position of the respondents & Architect/project manager & Project planner/project manager \\
\hline
\end{tabular}

D1 is a publicly listed Malaysian company involved mainly in property development. Besides receiving awards from The Edge Malaysia, the company has received other developers' awards. D1 was the first runner up of the top ten developers' awards 2016. Developer 1's operations are spread across three key economic regions in Malaysia with seventeen development projects in total, including new townships, integrated commercial developments, luxury high-rise apartments and green business parks. Company D2 has no green projects, but has won numerous awards including The Edge Top Ten Developers Award for eleven consecutive years, two times winner in the residential category for The Edge Awards in 2010 and 2011 for value creation excellence, and a merit winner in 2013. The many other awards that this company has received attest to its success in construction and development.

3.2.1.1. Drivers of green building project delivery for the case study companies

A number of detailed semi-structured interview questions were asked to discover the drivers and strategies of green building project delivery according to the respondents' opinions and the companies' experiences. The discussion included the interviewees' and their companies' values and attitudes regarding green building project delivery and the extent to which the internal 
drivers (that is, values and attitudes) and external drivers (social and cultural, and economic) affected the companies' decision to deliver a green housing development project.

\section{- Values and attitudes}

The developers gave different feedback on their commitment to delivering green projects. The feedback revealed that the developer with green building project experience was serious about green development, to the extent that it has its own green councils to assist the projects. The interviewee in D1 said that delivering green development projects is part of the company obligations and responsibilities. In the business sense, delivering green building projects contributes to the company's marketing strategy, helping to strengthen the company's brand. In conjunction with the seriousness of its green development, D1 has established four key strategic initiatives; that is, to develop green projects, foster green awareness, conduct green research and development, and promote a green image. The implementation of these four initiatives includes ensuring that the green project element meets a minimum green standard, raising awareness and educating their staff and customers on "going green", investing in research and developing intelligence in order to achieve their green goals, and ensuring that the company's branding is in line with the company's vision and mission. From the perspective of the D2 interviewee, the company became aware of Malaysia's commitment to green building development a long time ago. However, they discussed the related issues without taking serious action. Based on the interviews, it is evident that the developer with green projects (D1) agreed that values and attitudes had affected their company's decision to deliver green building projects. Full support from management is a major driver of the green project decision. However, the developer without green projects (D2) was unsure about the benefits of green development. The management has not been willing to commit to any green projects and the main obstacle is the perceived unlikelihood of gaining profit from green investment.

\section{- Social and cultural drivers}

Social support involves commitment from many different parties; for example, corporate, government, public, and company employee commitment. The D1 interviewee stated that amongst the social support that encourages the company to adopt a green agenda are the overall green campaign and charity events relating to recycling and green practice. Awareness about green development is very important for the company management team and the public in encouraging green project delivery. Since D2 has not committed to any green projects, no social support influences their decision to become involves in green projects. D2's management did not seriously consider this issue because of a lack of understanding about green practice. Awareness among developers and the public is important, but has not encouraged the D2 company to "go green". Moreover, the government has not enforced mandatory green development. The company believes that green building does provide benefits for people and the environment but creates many disadvantages for the developers.

\section{- Economic drivers}

Various incentives are given to developers to encourage them to deliver green building projects. D1 received government incentives such as tax exemption for its green projects, encouraging the company to deliver green projects. However, the interviewee suggested that the incentives should be increased to show government support and concern for green development. By contrast, D2 has not yet become involved in the green market, being uncertain about the incentives that are available. The D2 interviewee does not agree that the current incentives will encourage developers to deliver green projects and stated that the tax exemption was allocated according to income, not cost. This makes the exemption unattractive because costs are high but profit margins are low, and the developer has to achieve certain green standards in order to obtain incentives. The company believes that incentives do not support high cost development and are unfavorable to the D2 company. 


\subsubsection{Strategies to encourage green building project delivery in housing development}

The quantitative (questionnaire) and qualitative (case study interview) results show that social and cultural factors are the main drivers of green building project delivery. Attitudes, values, and economic factors have some influence but do not directly impact project delivery. Thus, the suggested strategies that encourage green project delivery should take this into account and integrate the social and cultural dimensions. This assertion was supported by the interviewees from both developers. There were several suggestions from D1 about how to encourage housing developers to deliver green projects. The first is to set a good example of green development for other developers in order to increase their interest in green projects. The second is to create competitiveness in green development. D2 expressed the opinion that high motivation is necessary to deliver a green market without government enforcement since developers are allowed to decide the type of development that will benefit the company. Therefore, the government should provide appropriate special schemes and insist on green practices. The green home should be affordable and buyers need to have green awareness and a willingness to pay more for a better product. Both D1 and D2 gave their opinions on strategies to encourage the green building project delivery by housing developers, particularly by integrating the social and cultural dimensions as presented in Table 6 (column C). Only the highest scoring strategies were taken into account when formulating suggested strategies. Eight of them were omitted from the list, but eleven strategies were presented at the expert interview stage for validation.

\subsubsection{Expert interview analysis}

The experts were drawn from GreenTech Malaysia (E1), MGBC (E2), MEGTW (E3), Company A (E4), and Company B (E5). GreenTech Malaysia is an organization under the control of the MEGTW, charged with catalyzing green technology deployment as a strategic engine for socio-economic growth in Malaysia in line with the National Green Technology Policy 2009. MGBC is a non-profit organization that promotes green buildings in Malaysia. MEGTW's role and responsibility is to plan and formulate policies and programs for green technology in Malaysia. In 2018, the name of this ministry was changed to Ministry of Energy, Technology, Science, Climate Change and Environment. Two practicing experts were involved throughout the validation process. One was an expert from an established developer who had delivered many green development projects (Company A) and the other an expert from another established and well-known company representing developers without a green project perspective (Company B). Table 6 (column D-F) shows the experts' opinions on strategies to encourage green building project delivery by developers. These strategies can be developed by integrating the social and cultural dimensions covered in the previous process. Based on the results, eleven strategies were considered significant for encouraging green project delivery. In particular, the experts picked four main strategies, as follows: "encourage corporate commitment to supporting the green building market in order to keep it stable", "provide education with regard to the economic viability of green building development for developers and buyers", "educate building occupants on practicing sustainable behaviors", and "provide proper education, training, and advocacy by the government on green building processes, practices, and skills" These were followed by the remaining seven strategies. These strategies were then ranked and divided into six categories: "corporate commitment and education relating to economic factors", "education relating to the concept, benefits, and operation of green buildings", "technical and financial support from various sectors", "green market support", "foster willingness among stakeholders", and "ensure that the public is well informed." 
Table 6 Developers' and experts' views on strategies to encourage green building project

\begin{tabular}{|c|c|c|c|c|c|}
\hline $\mathrm{A}$ & $\mathrm{B}$ & $\mathrm{C}$ & $\mathrm{D}$ & $\mathrm{E}$ & $F$ \\
\hline \multirow{3}{*}{ No. } & \multirow{3}{*}{$\begin{array}{l}\text { Strategies that integrate social and cultural factors to } \\
\text { encourage the delivery of green housing projects }\end{array}$} & \multicolumn{4}{|c|}{ Level of Agreement } \\
\hline & & Developers & Experts & Rank & Category \\
\hline & & Scores & Scores & & \\
\hline 1. & $\begin{array}{l}\text { Establish environmental NGOs to ensure that the public } \\
\text { is better informed about green building benefits and } \\
\text { performance }\end{array}$ & $\begin{array}{l}\text { High } \\
(10)\end{array}$ & $\begin{array}{l}\text { Moderate } \\
(16)\end{array}$ & 5 & $\begin{array}{l}\text { To ensure that the } \\
\text { public is well } \\
\text { informed. }\end{array}$ \\
\hline 2. & $\begin{array}{l}\text { Encourage the application of passive design in green } \\
\text { building construction to improve productivity and } \\
\text { reduce the construction costs of green technology }\end{array}$ & $\begin{array}{l}\text { Low } \\
(4)\end{array}$ & Omitted & & \\
\hline 3. & $\begin{array}{l}\text { Generate demand for green products for their } \\
\text { environmental and health benefits, and achieve higher } \\
\text { returns on investment in green buildings }\end{array}$ & $\begin{array}{l}\text { Low } \\
(4)\end{array}$ & Omitted & & \\
\hline 4. & $\begin{array}{l}\text { Encourage corporate commitment to supporting the } \\
\text { green building market in order to keep it stable }\end{array}$ & $\begin{array}{l}\text { High } \\
(10)\end{array}$ & $\begin{array}{l}\text { High } \\
(23)\end{array}$ & 1 & $\begin{array}{l}\text { Corporate } \\
\text { commitment and } \\
\text { education relating } \\
\text { to economic } \\
\text { factors }\end{array}$ \\
\hline 5. & $\begin{array}{l}\text { Obtain comprehensive technical and financial support } \\
\text { from NGOs, professional boards, the private sector, } \\
\text { government owned banks, and others for energy } \\
\text { efficient buildings }\end{array}$ & $\begin{array}{l}\text { High } \\
(10)\end{array}$ & $\begin{array}{l}\text { Moderate } \\
\text { (17) }\end{array}$ & 4 & $\begin{array}{l}\text { Technical and } \\
\text { financial support } \\
\text { from various } \\
\text { sectors }\end{array}$ \\
\hline 6. & $\begin{array}{l}\text { Encourage the private sector, service providers, and } \\
\text { professional services providers to offer green and } \\
\text { energy efficient products and services }\end{array}$ & $\begin{array}{l}\text { High } \\
(10)\end{array}$ & $\begin{array}{l}\text { Moderate } \\
\text { (17) }\end{array}$ & 4 & Green market \\
\hline 7. & $\begin{array}{l}\text { Increase the supply of local green materials and green } \\
\text { technology in the market. }\end{array}$ & $\begin{array}{l}\text { High } \\
(10)\end{array}$ & $\begin{array}{l}\text { Moderate } \\
(17)\end{array}$ & 4 & support \\
\hline 8. & $\begin{array}{l}\text { Encourage corporate social responsibility to ensure that } \\
\text { developers volunteer to address environmental } \\
\text { problems like climate change }\end{array}$ & $\begin{array}{l}\text { Moderate } \\
(7)\end{array}$ & Omitted & & \\
\hline 9. & $\begin{array}{l}\text { Provide proper education, training, and advocacy on } \\
\text { green building processes, practices, and skills via the } \\
\text { government }\end{array}$ & $\begin{array}{l}\text { High } \\
(10)\end{array}$ & $\begin{array}{l}\text { High } \\
(21)\end{array}$ & 5 & $\begin{array}{l}\text { To ensure that the } \\
\text { public is well } \\
\text { informed. }\end{array}$ \\
\hline 10. & $\begin{array}{l}\text { Provide education with regard to the economic viability } \\
\text { of green building development for developers and } \\
\text { buyers }\end{array}$ & $\begin{array}{l}\text { High } \\
(10)\end{array}$ & $\begin{array}{l}\text { High } \\
(22)\end{array}$ & & \\
\hline 11. & $\begin{array}{l}\text { Encourage the willingness to commit to sustainable } \\
\text { development among developers to deliver successful } \\
\text { green projects }\end{array}$ & $\begin{array}{l}\text { High } \\
(10)\end{array}$ & $\begin{array}{l}\text { Moderate } \\
\text { (17) }\end{array}$ & & \\
\hline 12. & $\begin{array}{l}\text { Convince buyers and encourage sustainable business } \\
\text { purchases }\end{array}$ & $\begin{array}{l}\text { High } \\
(10)\end{array}$ & $\begin{array}{l}\text { Moderate } \\
\text { (17) }\end{array}$ & 1 & $\begin{array}{l}\text { Corporate } \\
\text { commitment and } \\
\text { education relating } \\
\text { to economic } \\
\text { factors }\end{array}$ \\
\hline & $\begin{array}{l}\text { Develop competition in the green building market to } \\
\text { increase the demand for green development }\end{array}$ & $\begin{array}{l}\text { Moderate } \\
\text { (7) }\end{array}$ & Omitted & 4 & $\begin{array}{l}\text { Technical and } \\
\text { financial support } \\
\text { from various } \\
\text { sectors }\end{array}$ \\
\hline 14. & $\begin{array}{l}\text { Provide education on green resources, markets, and } \\
\text { materials in order to promote the needs and business of } \\
\text { green building }\end{array}$ & $\begin{array}{l}\text { Moderate } \\
\text { (7) }\end{array}$ & Omitted & 4 & $\begin{array}{l}\text { Green market } \\
\text { support }\end{array}$ \\
\hline 15. & $\begin{array}{l}\text { Educate building occupants in practicing sustainable } \\
\text { behaviors }\end{array}$ & $\begin{array}{l}\text { High } \\
(10)\end{array}$ & $\begin{array}{l}\text { High } \\
(22)\end{array}$ & 4 & \\
\hline 16. & $\begin{array}{l}\text { Provide education that green building implementation } \\
\text { should go beyond environmental criteria (for example, } \\
\text { the use of interior materials that help to improve the } \\
\text { health of occupants) }\end{array}$ & $\begin{array}{l}\text { Low } \\
\text { (4) }\end{array}$ & Omitted & & \\
\hline
\end{tabular}




\begin{tabular}{|c|c|c|c|c|c|}
\hline A & B & $\mathrm{C}$ & $\mathrm{D}$ & $\mathrm{E}$ & $\mathrm{F}$ \\
\hline \multirow{3}{*}{ No. } & \multirow{3}{*}{$\begin{array}{l}\text { Strategies that integrate social and cultural factors to } \\
\text { encourage the delivery of green housing projects }\end{array}$} & \multicolumn{4}{|c|}{ Level of Agreement } \\
\hline & & Developers & Experts & Rank & Category \\
\hline & & Scores & Scores & & \\
\hline 17. & $\begin{array}{l}\text { Encourage collaboration among building owners and } \\
\text { tenants to gain benefits for both parties in green } \\
\text { developments }\end{array}$ & $\begin{array}{l}\text { Moderate } \\
(7)\end{array}$ & Omitted & & \\
\hline 18. & $\begin{array}{l}\text { Encourage the owners to use high efficiency appliances } \\
\text { to enjoy green building benefits }\end{array}$ & $\begin{array}{l}\text { High } \\
(10)\end{array}$ & $\begin{array}{l}\text { Moderate } \\
(17)\end{array}$ & 4 & $\begin{array}{l}\text { To increase } \\
\text { willingness among } \\
\text { stakeholders }\end{array}$ \\
\hline
\end{tabular}

Notes: - Developers' agreement scoring guide: 1-4 (low), 5-7 (moderate), 8-10 (high)

- Experts' agreement scoring guide:1-8(low), 9-17 (moderate), 18-25 (high)

Corporations should continue and expand their support for the green market. The government should provide more attractive incentives for developers to voluntarily adopt green building practices in addition to the Green Technology Financing Scheme (GTFS) and the Malaysian Green Foundation or Yayasan Hijau Malaysia (YaHijau) in order to play an effective role in promoting and enhancing the corporate community's and the general public's awareness of the technology and practice of green living. The involvement of corporate bodies through corporate social responsibility (CSR) programs and the contribution of funds might indirectly encourage the involvement of the private or corporate bodies and raise awareness of the important responsibility to cooperate in order to realize the national agenda. Green concepts in building development should be supported by corporate committees in order to give developers a sound knowledge and experience of green development. Provision of education with regard to the economic viability of green building development for developers and buyers is very important. This strategy should be introduced to increase education and awareness of the green concept for implementation in future development projects. These approaches must be followed because they have the potential to produce talent and expertise in green development. For instance, a green building component should be included in the curricula of relevant courses in university and other higher education institutes. This culture has grown in developed countries such as Singapore, which has successful green building development. The government should provide grants for academic research and training. This strategy is efficient in encouraging the delivery of green building projects and must be introduced in the early stages of projects. Moreover, building occupants should be educated in practicing sustainable green behaviors because only people thus educated understand and practice energy saving measures. Developers and buyers should be informed that green building is not necessarily expensive, but can provide significant value for money.

\section{CONCLUSION}

This research began by critically examining housing development issues relating to the rapid growth of urbanization in the KV area. Conventional housing projects that are not green have caused the temperature within this area to increase dramatically and contributed to global warming. While buildings play an important role in urban development by meeting the basic need for human shelter, they have also been identified as major consumers of energy, water, raw materials, and land use that contribute to environmental depletion. Green building is an innovation that improves the quality of indoor and outdoor environments, benefiting building occupants' health and wellbeing and making it a crucial practice for future environmental sustainability. However, the level of green project delivery in housing development is still low. Thus, this paper aims to explore drivers and strategies for encouraging green project delivery in housing development, specifically in KV. 
In the first stage, with the help of the PEB model, the variables of external and internal drivers were identified. Data was analyzed using descriptive statistics, Cronbach's alpha, correlation, and multiple regressions. Thus, social and cultural drivers were identified as the main drivers of green housing development in $\mathrm{KV}$. Therefore, to encourage green building project delivery, several strategies were suggested that considered social and cultural factors. The results from the questionnaire survey were supplemented by two case study interviews to confirm how those drivers affected two development companies with different practices in housing development; that is, green projects and conventional projects. The interview protocol was developed based on the results of quantitative analysis. In the final stage, the identified drivers and strategies from the questionnaires and case studies were validated through semi-structured expert interviews. Consequently, based on the interviews eleven strategies, grouped into four categories that integrate social and cultural factors, were proposed in order to encourage delivery of green building projects in housing development.

In short, green development should be widely promoted by the government via green-friendly development policies and encouragement of the use of innovative green technologies by its Ministries. To ensure inclusive and sustainable development, a proactive approach that integrates social and cultural factors is needed. It should be based on deeply rooted knowledge of the local context and involve the participation of marginalized groups. The overriding findings of this research show that the most crucial drivers affecting green building project delivery are the social and cultural drivers. The provision of green building education, training, and various incentives, such as enhancing the availability of sustainable materials, technology, and expertise, by the government sector would dramatically improve the delivery of green building projects by the housing developers. Additionally, values, attitudes, and economic drivers are within the control of developers' personnel and management and everyone should play their part in making green building development a success.

\section{ACKNOWLEDGEMENT}

This work was supported by the Malaysian Ministry of Higher Education and Sultan Idris Education University under FRGS grant no. 2017-0081-108-02.

\section{REFERENCES}

Albahori, A.S., Isa, N.K.M., 2017. A Correlative Study between Internal Factors and the Implementation of the Green Building Development among the Housing Developers in Klang Valley, Malaysia. Journal of Engineering and Applied Sciences, Volume 12(19), pp. 5035-5042

Albahori, A.S., Isa, N.K.M., Yunos, M.Y.M., Marzuki, M., 2017. The Association between External Factors and the Implementation of the Green Building Principles among Housing Developers in Klang Valley. Malaysian Construction Research Journal, MCRJ, 2017 Special Issue, Volume 2(2), pp. 48-61

APEC, 2014. APEC Energy Overview 2014. Asia Pacific Energy Research Centre (APERC). Available Online at: https://aperc.ieej.or.jp/file/2015/6/19/APEC_Energy_Overview_2014.pdf

Chua, S.C., Oh, T.H., 2011. Green Progress and Prospect in Malaysia. Renewable and Sustainable Energy Reviews, Volume 15(6), pp. 2850-2861

Ekman, P., 1992. An Argument for Basic Emotions. Cognition \& Emotion, Volume 6(3-4), pp. $169-200$

Green Building Index (GBI)., 2017. Executive Summary as of 15 February 2017. Green Building Index. Available http://new.greenbuildingindex.org/organisation/summary 
Isa, N.K.M., Alias, A., Samad, Z.A., 2017. Sustainable Building through the Project Planning Process: The Case of Malaysia. University Malaya Press, Malaysia, pp. 1-207

Isa, N.K.M., Alias, A., Samad, Z.A., Yunos, M.Y.M., 2015, Establishing Project Performance and Sustainability Principles: A Case Study on the Diamond Building Project. Australian Journal of Basic and Applied Sciences, Volume 9(7), pp. 176-178

Isa, N.K.M., Yunos, M.Y.M., Ismail. K., Marzuki, M., 2018. Sustainability Goals and Project Success from the Perspective of the Stakeholders of Green Building Projects in Malaysia: A Preliminary Study. Perspektif - Jurnal Sains Sosial dan Kemanusiaan, Volume 10(1), pp. 21-32

Kollmuss, A., Agyeman, J., 2002. Mind the Gap: Why Do People Act Environmentally and What Are the Barriers to Pro-environmental Behavior? Environmental Education Research, Volume 8(3), pp. 239-260

Krejcie, R.V., Morgan, D.W., 1970. Determining Sample Size for Research Activities. Educational and Psychological Measurement, Volume 30(3), pp. 607-610

Kruger, A., Seville, C., 2013. Green Building: Practices in Residential Construction. Delmar, Cengage Learning, United States of America, pp. 1-521

Li, Y.Y., Chen, P.H., Chew, D.A.S., Teo, C.C., 2014. Exploration of Critical Resources and Capabilities of Design Firms for Delivering Green Building Projects: Empirical Studies in Singapore. Habitat International, Volume 41, pp. 229-235

Ministry of Housing and Local Government (MHLG), 2017. The list of Housing Projects in Klang Valley. Private Housing Monitoring Division, Department of Housing, Ministry of Housing and Local Government Malaysia: Government Report. (Unpublished report)

Mordkoff, J.T., 2016. The Assumption(s) of Normality. Available Online at: http://www2.psychology.uiowa.edu/faculty/mordkoff/GradStats/part\%201/I.07\%20normal. pdf

Samari, M., Mirhosseini, S.M., Esmaeilifar, R., Mohd Wira, M.S., 2015. Market Barriers to Implementing Sustainable Building in Malaysia. Advances in Environmental Biology, Volume 9(5), pp. 135-138

Statistics Solutions, 2013. Normality. Available Online at: http://www.statisticssolutions.com/academic-solutions/resources/directory-of-statisticalanalyses/normality/

Tan, T.H., 2011. Sustainability and Housing Provision in Malaysia. Journal of Strategic Innovation and Sustainability, Volume 7(1), pp. 62-71

The Government of Malaysia, 2015. Rancangan Malaysia Kesebelas 2016-2020. Pertumbuhan Berpaksikan Rakyat (The Eleventh Malaysia Design 2016-2020. People Working Growth). Available Online at: https://www.pmo.gov.my/dokumenattached/speech/files/RMK11_Speech.pdf 